\title{
The Place of Atopy in the Aetiology of Acute Appendicitis in Children
}

\author{
MN Cevizci ${ }^{1}$, A Sogut ${ }^{2}$, A Cayir ${ }^{3}, \mathrm{M} \mathrm{Demir}^{1}$, SA Ozman ${ }^{4}$, F Erdoğan
}

\begin{abstract}
Objective: Appendicitis, the most common cause of abdominal pain requiring surgery in children, refers to inflammation of the vermiform appendix. The aetiology of appendicitis is multifactorial, although it is affected by several precursor factors. The purpose of this study was to investigate whether allergic diseases cause a predisposition to appendicitis. Subjects and Methods: One hundred and sixteen patients who underwent surgery for acute appendicitis and who had a diagnosis of acute appendicitis confirmed pathologically, and a control group of 124 individuals of similar ages and genders, were enrolled. The level of inflammation of appendiceal material in cases diagnosed with acute appendicitis was classified pathologically. The skin prick test (SPT) was used to determine allergic sensitization. Results: A significant difference was determined between the patient and control groups in terms of skin prick positivity $(p<0.05)$.

Conclusion: While there are several known factors implicated in the causation of acute appendicitis, the cause cannot be identified in some cases. We think that atopy may also be a risk factor in the development of acute appendicitis.
\end{abstract}

Keywords: Acute appendicitis, atopy, child

\section{Lugar de la atopía en la etiología de la apendicitis aguda en niños MN Cevizci ${ }^{1}$, A Sogut ${ }^{2}$, A Cayir 3 , M Demir ${ }^{1}$, SA Ozman $^{4}$, F Erdoğan ${ }^{4}$}

\begin{abstract}
RESUMEN
Objetivos: La apendicitis, la causa más común de dolor abdominal que requiere cirugía en niños, consiste en la inflamación del apéndice vermiforme. La etiología de la apendicitis es multifactorial, aunque es afectada por varios factores precursores. El propósito de este estudio era investigar si las enfermedades alérgicas provocan una predisposición a la apendicitis. Sujetos y métodos: El estudio abarcó por un lado a ciento dieciséis pacientes que habian sido sometidos a cirugía por apendicitis aguda, luego de un diagnóstico de apendicitis aguda confirma da patológicamente, y por otro, un grupo control de 124 individuos de edades y géneros similares. El nivel de inflamación del material apendicular en casos diagnosticados con apendicitis aguda se clasificó patológicamente. La prueba intraepidérmica de alergia o puntura cutánea (SPT), se utilizó para determinar la sensibilidad alérgica.

Resultados: Se halló una diferencia significativa entre los pacientes y el grupo de control en cuanto a la positividad del pinchazo de la piel $(p<0.05)$.

Conclusión: Si bien existen varios factores conocidos implicados en la causa de la apendicitis aguda, la causa no puede identificarse en algunos casos. Pensamos que la atopía también puede ser un factor de riesgo en el desarrollo de la apendicitis aguda.
\end{abstract}

Palabras claves: Apendicitis aguda, atopía, niño

West Indian Med J 2016; 65 (2): 287

From: ${ }^{1}$ Department of Pediatric Surgery, ${ }^{2}$ Department of Pediatric Allergy and Immunology, ${ }^{3}$ Department of Pediatrics and ${ }^{4}$ Department of Pathology, Regional Training and Research Hospital, Erzurum, Turkey.
Correspondence: Dr A Cayir, Department of Pediatrics, Regional Training and Research Hospital, Erzurum, Turkey. Fax: + 04422325090; e-mail: dratillacayir@gmail.com 


\section{INTRODUCTION}

Appendicitis refers to inflammation of the vermiform appendix. It is the most common cause of abdominal pain requiring surgery in children. Seven per cent of people undergo surgery for appendicitis during their lifetime. In addition, accurate diagnosis remains at a level of $72-94 \%$, showing that diagnosis is still problematic (1-3).

The most significant causative factor in acute appendicitis is obstruction of the lumen. The more severe the inflammatory event in the appendix, the higher the probability of lumen obstruction. Faecaliths, hypertrophy of lymphoid tissue, fruit and vegetable seeds and intestinal parasites may lead to obstruction of the appendiceal lumen. The aetiology of appendicitis is multifactorial, although it is affected by several precursor factors. While there are several known factors in acute appendicitis, the cause cannot be identified in some cases. Consideration of age, gender, familial disposition and seasonal characteristics at assessment will therefore assist diagnosis in children presenting with abdominal pain (3-5).

The purpose of this study was to determine whether or not inflammation and lymphoid hyperplasia that may occur in allergic diseases cause a disposition to appendicitis by leading to obstruction in the appendiceal lumen.

\section{SUBJECTS AND METHODS}

One hundred and sixteen patients with a diagnosis of acute appendicitis who underwent surgery at the Erzurum Regional Education and Research Hospital between September 2012 and September 2013, and in whom diagnosis was confirmed pathologically, together with a control group of 124 members similar in age and gender, were enrolled. The control group consisted of patients attending the paediatric surgery unit for other reasons, such as circumcision or hernia. The study was performed in compliance with the principles of the Helsinki Declaration. All parents of patients and control groups were informed about the study and gave written consent. The study was approved by the local ethics committee.

Exclusion criteria included:

- Refusal to participate in the study

- History of using antihistaminic or antiallergenic drugs in the previous week

- Presence of intra-abdominal abscess, generalized peritontis nitis, shock on admission, history of cirrhosis and coagulation disorders or contraindication of general anaesthia.

Diagnosis of appendicitis was considered in patients with an initial history of nausea, vomiting and lack of appetite, with abdominal tenderness in the lower right quadrant and fever on physical examination, and with leukocytosis at laboratory investigation. X-ray and abdominal ultrasound were used to support diagnosis and for differential diagnosis. Patients were given ampicillin-sulbactam $150 \mathrm{mg} / \mathrm{kg}$ per day in three equal doses starting 12 hours before going into surgery. Postoperative ornidazole $30 \mathrm{mg} / \mathrm{kg}$ per day in three doses and aminoglycoside $15 / \mathrm{mg} / \mathrm{kg}$ per day in two doses were added in cases in which perforation was observed intraoperatively. Ap- pendectomy was performed with the appendiceal stump being sutured twice with absorbable suture (polyglactin).

\section{Pathological investigation}

A section was taken every centimeter at macroscopic examination of appendectomy materials. Sections stained with haematoxylin-eosin were subjected to histopathological examination. Diagnosis of acute appendicitis was based on presence of polymorphonuclear leukocyte infiltration in the muscular wall of the appendix. Presence and spread of eosinophil leukocyte infiltration were analysed. The areas with the greatest leukocyte presence were determined under low magnification. A three-stage classification was performed in these areas using a semi-quantitative method: negative ( -$)$, low positive $(1+)$, moderate positive $(2+)$ and strongly positive $(3+)$.

Level of inflammation in cases diagnosed as acute appendicitis during examination was classified under four degrees: suppurative appendicitis limited to the mucosa, suppurative appendicitis limited to the wall, periappendicitis (neutrophil leukocytes in fatty tissue) and perforation or peritonitis.

Allergic sensitization was demonstrated using the skin prick test (SPT). This was performed following European Academy of Allergology and Clinical Immunology guidelines (6). Skin prick test was conducted using a standard allergen extract panel (Allergopharma, Germany) and included histamine $(10 \mathrm{mg} / \mathrm{mL}$ of histamine phosphate) as positive and $0.9 \%$ sterile saline as negative controls, aeroallergens (grasses, trees, herbs, cereals, willow tree, olive, Dermatophagoides farinae, Dermatophagoides pteronyssinus, Alternaria alternata, Aspergillus fumigatus, Cladosporium herbarum, feline epithelia, canine epithelia and budgerigar feathers) and food allergens (cow's milk, chicken egg, cocoa, strawberry, tomato, kiwi, banana, hazelnut, peanut, peach, walnut, pear, chicken meat, mutton, beef and tuna). The SPT was considered positive if the mean wheal diameter was $\geq 3 \mathrm{~mm}$ compared with the negative control (7).

\section{Statistical analysis}

Frequencies and percentages are given for nominal data and mean \pm standard deviation for continuous data as descriptive statistics. Data were subjected to Pearson's Chi-squared test and the independent sample $t$-tests on Statistical Package for Social Sciences 18.0 (Armonk, NY, USA) software. Significance was set at $p \leq 0.05$. The results are expressed as mean \pm SD.

\section{RESULTS}

Two hundred and forty children were enrolled in the study: $116(48 \%)$ who underwent surgery for acute appendicitis and 124 (58\%) controls. Demographic characteristics of the study and control groups are shown in Table 1.

Inhalant positivity was determined in six $(5.2 \%)$, food positivity in eight $(6.9 \%)$ and inhalant and food positivity in eight $(6.9 \%)$ patients with the SPT. The respective numbers in the control group were three $(2.4 \%)$, two $(1.6 \%)$ and one $(0.8 \%)$. No statistically significant difference was determined 
between the patient and control groups in terms of skin prick positivity $(p>0.05)$. Data concerning the comparison of SPT results with degree of severity of acute appendicitis in the study group are shown in Table 2.

Table 1: Demographic characteristics of the study and control groups

\begin{tabular}{lccc}
\hline & Study group & Control group & $\boldsymbol{p}$-value \\
\hline Age & $10.1 \pm 2.9$ & $9.8 \pm 2.6$ & $>0.05$ \\
Male/female & $71 / 45$ & $69 / 55$ & $>0.05$ \\
Leukocyte number & $14186 \pm 4429$ & $7052 \pm 1690$ & $<0.05^{*}$ \\
Eosinophil number & $1.31 \pm 0.6$ & $1.18 \pm 0.4$ & $>0.05$ \\
\hline
\end{tabular}

$* p<0.05$ was regarded as significant

Table 2: Comparison of appendicitis with degree of histological severity, Alvarado and skin tests

$\begin{array}{cccc}\begin{array}{c}\text { Inhalant allergen } \\ \text { positive group }\end{array} & \begin{array}{l}\text { Food allergen } \\ \text { positive group }\end{array} & \begin{array}{l}\text { Inhalant and } \\ \text { food allergen } \\ \text { positive group }\end{array} & \begin{array}{l}\text { Inhalant and } \\ \text { food allergen } \\ \text { negative group }\end{array}\end{array}$

\begin{tabular}{llllll}
\hline $\begin{array}{l}\text { Acute } \\
\text { appendicitis }\end{array}$ & 0 & $3(2.6 \%)$ & $2(1.7 \%)$ & $20(17.2 \%)$ & \\
$\begin{array}{l}\text { Suppurative } \\
\text { appendicitis }\end{array}$ & $2(1.7 \%)$ & $1(0.9 \%)$ & $1(0.9 \%)$ & $25(21.6 \%)$ & $>0.05$ \\
$\begin{array}{l}\text { Periappendicitis } \\
\begin{array}{l}\text { Perforated } \\
\text { appendicitis }\end{array}\end{array}$ & $4(3.4 \%)$ & $4(3.4 \%)$ & $5(4.3 \%)$ & $43(37.1 \%)$ & \\
$* 0<0.05$ was regarded as significant & 0 & 0 & $6(5.2 \%)$ & \\
\hline$* p<0$
\end{tabular}

$* p<0.05$ was regarded as significant

\section{DISCUSSION}

Acute appendicitis is common in boys after the age of 10 years. The incidence of appendicitis is between 1.1 and 2.9 times higher in males. Obstruction in the lumen is involved in the aetiology of $85 \%$ of cases, while the aetiology is unknown in $15 \%(4,5,8)$.

Communication difficulties, difficulty in performing physical examination, obesity and sometimes gynaecological disorders in young girls may reduce the accuracy of diagnosis of acute appendicitis. Age, gender, season, genetics and other probable factors must be examined for that purpose and their place in accurate diagnosis must be revealed. Despite the concentration on several factors, others are still the subject of debate $(9,10)$.

This study investigated whether or not atopy is a risk factor for appendicitis. Significantly greater prick test positivity was determined in patients operated on for appendicitis compared to the control group. This finding suggests that atopy may be a risk factor in the development of appendicitis.

While a correlation has been determined between incidence of appendicitis and the seasons, the subject of which season has the highest incidence is still controversial. Some studies have reported that appendicitis is more common in summer and others in winter. It has been suggested that the seasonal variation in appendicitis in studies is more associated with climatic features in the place where the study was performed, such as humidity and rainfall or bacterial or viral infections that increase with these seasons, rather than air temperature. These variable factors may increase the risk of appendicitis by causing atopy to develop or increasing the severity of existing atopy $(3,4,11,12)$.

Lymphoid tissue forms in the appendix wall soon after birth. Between the ages of 12 and 20 years, there are some 200 lymphoid follicles in the appendix. The physiological function of the appendix is largely concerned with the immune system and plays a role in the maturation of B lymphocytes $(13,14)$. Recent studies have shown that the appendix is involved in the production of $\mathrm{B}$ and $\mathrm{T}$ lymphocytes and immunoglobulin from childhood to old age (15). Since the appendix plays an effective role in the immune system, the incidence of colorectal cancer and ulcerative colitis increases after appendectomy (13).

Inability of appendiceal secretions to drain leads to congestion in the appendix, followed by appendicitis. Two mechanisms affect occlusion of the appendiceal orifice: proliferation of lymphoid tissue and presence of faecaliths. Proliferation of lymphoid tissue is the most important factor affecting appendiceal drainage. Since lymphoid tissue is more pronounced in young people than in the elderly, occlusion is also more common. Following occlusion of the appendiceal orifice, bacterial translocation occurs in association with an increase in congestion, distension and intraluminal pressure. If congestion leads to rapid pronounced transmural ischaemia, necrosis and perforation quickly appear in the appendix. If congestion occurs in the long term, appendiceal abscess or phlegmon develop. Factors that may cause an increase in lymphoid tissue activity may therefore cause an increased risk of appendicitis $(14,16,17)$.

Atopy involves the synthesis of IgE antibody against allergens frequently encountered in the environment. Atopy is seen in some individuals with a disposition to IgE-related diseases such as allergic rhinitis, asthma and atopic dermatitis. Serum $\operatorname{IgE}$ and eosinophil levels are often elevated in atopic individuals (18-20).

Although there was no statistically significant difference between our patients operated on for appendicitis and the control group in terms of $\operatorname{IgE}$ and eosinophil values, the fact that they were higher in the former supports our current finding.

Our review of the literature revealed no similar studies in the paediatric population. In conclusion, we think that atopy may be a risk factor for the development of acute appendicitis. One limitation of this study is that the risk of appendicitis compared to the normal population was not established with long-term observation of children with atopy. Therefore, the risk of appendicitis in these patients should be evaluated through retrospective research in centres where patients with atopy are monitored.

\section{REFERENCES}

1. Karabulut R, Sonmez K, Turkyilmaz Z, Demirogullari B, Ozen IO, Demirtola A et al. Negative appendectomy experience in children. Ir J Med Sci 2011; 180: 55-8.

2. Ates M, Coban S, Sevil S, Terzi A. The efficacy of laparoscopic surgery in patients with peritonitis. Surg Laparosc Endosc Percutan Tech 2008; 18: $453-6$. 
3. Deng Y, Chang DC, Zhang Y, Webb J, Gabre-Kidan A, Abdullah F. Seasonal and day of the week variations of perforated appendicitis in US children. Pediatr Surg Int 2010; 26: 691-6.

4. Sulu B, Günerhan Y, Palanci Y, Işler B, Cağlayan K. Epidemiological and demographic features of appendicitis and influences of several environmental factors. Ulus Travma Acil Cerrahi Derg 2010; 16: 38-42.

5. Al-Omran M, Mamdani M, McLeod RS. Epidemiologic features of acute appendicitis in Ontario, Canada. Can J Surg 2003; 46: 263-8.

6. Zuberbier T, Asero R, Bindslev-Jensen C, Walter Canonica G, Church MK, Giménez-Arnau AM et al; Dermatology Section of the European Academy of Allergology and Clinical Immunology; Global Allergy and Asthma European Network; European Dermatology Forum; World Allergy Organization. EAACI/GA(2)LEN/EDF/WAO guideline: management of urticaria. Allergy 2009; 64: 1427-43.

7. Dreborg S, Backman A, Basomba A. Skin tests used in type I allergy testing. Position paper. Allergy 1989; 44: S1-S59.

8. Shrestha R, Ranabhat SR, Tiwari M. Histopathologic analysis of appendectomy specimens. J Pathol Nepal 2012; 2: 215-9.

9. Oguntola AS, Adeoti ML, Oyemolade TA. Appendicitis: trends in incidence, age, sex, and seasonal variations in south-western Nigeria. Ann Afr Med 2010; 9: 213-7.

10. Kulik DM, Uleryk EM, Maguire JL. Does this child have appendicitis? A systematic review of clinical prediction rules for children with acute abdominal pain. J Clin Epidemiol 2013; 66: 95-104.

11. Lee JH, Park YS, Choi JS. The epidemiology of appendicitis and appendectomy in South Korea: national registry data. J Epidemiol 2010; 20: $97-105$.

12 Stein GY, Rath-Wolfson L, Zeidman A, Atar E, Marcus O, Joubran S et al. Sex differences in the epidemiology, seasonal variation, and trends in the management of patients with acute appendicitis. Langenbecks Arch Surg 2012; 397: 1087-92.

13. Shanahan F, O'Sullivan GC. Appendectomy, mucosal immunity, and colitis. Gastroenterology 1997; 112: 1766-77.

14. Rothrock SG, Pagane J. Acute appendicitis in children: emergency department diagnosis and management. Ann Emerg Med 2000; 36: $39-51$.

15. Dasso JF, Obiakor H, Bach H, Anderson AO, Mage RG. A morphological and immunological study of the human and rabbit appendix for comparison with the avian bursa. Dev Comp Immunol 2000; 24: 797-814.

16. Brogden TG, Streets CG. The management of acute appendicitis. J R Nav Med Serv 2013; 99: 106-10.

17. Simpson J, Speake W. Acute appendicitis. Clin Evid 2002; 7: 386-91.

18. Szefler SJ. The natural history of asthma and early intervention. J Allergy Clin Immunol 2002; 109: 549-53.

19. Warner JO, Götz M, Landau LI, Levison H, Milner AD, Pedersen S et al. Management of asthma: a consensus statement. Arch Dis Child 1989; 64: 1065-79.

20. Xuan W, Marks GB, Toelle BG, Belousova E, Peat JK, Berry G et al. Risk factors for onset and remission of atopy, wheeze, and airway hyperresponsiveness. Thorax 2002; 57: 104-9. 